\title{
New approaches regarding the in vitro maturation of oocytes: manipulating cyclic nucleotides and their partners in crime
}

\author{
Ramon Cesar Botigelli ${ }^{1}$, Eduardo Montanari Razza ${ }^{1}$, Elisa Mariano Pioltine ${ }^{1}$, Marcelo Fábio Gouveia Nogueira ${ }^{1,2}$ \\ ${ }^{1}$ Department of Pharmacology, Institute of Bioscience, University of São Paulo State, Botucatu, São Paulo, \\ Brazil \\ ${ }^{2}$ Department of Biological Sciences, Faculty of Sciences and Letters, University of São Paulo State, Assis, São \\ Paulo, Brazil
}

\begin{abstract}
Several discoveries have been described recently (510 years) about the biology of ovarian follicles (oocyte, cumulus cells and granulosa cells), including new aspects of cellular communication, the control of oocyte maturation and the acquisition of oocyte competence for fertilization and further embryo development. These advances are nourishing assisted reproduction techniques (ART) with new possibilities, in which novel culture systems are being developed and tested to improve embryo yield and quality. This mini-review aims to describe how the recent knowledge on the physiological aspects of mammalian oocyte is reflecting as original or revisited approaches into the context of embryo production. These new insights include recent findings on the mechanisms that control oocyte maturation, especially modulating intraoocyte levels of cyclic nucleotides during in vitro maturation using endogenous or exogenous agents. In this mini-review we also discuss the positive and negative effects of these manipulations on the outcoming embryo
\end{abstract}

Keywords: Oocytes, cumulus cells, oocyte in vitro maturation, cyclic nucleotides, in vitro oocyte maturation techniques

\section{BACKGROUND}

The literature concerning oocyte competence and embryo quality has become abundant in the last few years. Several factors are involved in oocyte metabolism, cyto-skeletal remodeling, accumulation of molecules (RNAs), meiosis arrest/resumption and fertilization, all of which are key events for initiating and sustaining early embryogenesis. This large amount of published data has allowed researchers to pursue new strategies in assisted reproduction techniques (ART). This mini-review focuses on the recent progress in understanding the events controlling the acquisition of competence in oocytes and the new mechanisms involved in the maintenance of oocyte meiotic arrest; and thus, it may yield future approaches regarding the development of novel systems of in vitro culture, and hopefully bring the status of in vitro production of embryos (IVP) to a whole new level. For the purpose of this mini-review the literature search was performed in the PubMed database, to find all relevant papers focusing in "mammalian oocyte maturation", "in vitro oocyte maturation techniques" and crossing data with "cyclic nucleotides" ("cyclic adenosine monophosphate", "cyclic guanosine monophosphate"), "meiosis arrest/resumption" and "embryo yield", from which we have selected 112 papers, among original and review papers, to discuss the most interesting findings and also included some of our own.

\section{INTRODUCTION}

Mammalian oocytes pass through a long and complex process to acquire the competence necessary for fertilization and embryogenesis. Oocytes are formed in fetal life, when the primordial germ cells (PGC), first seen in the epiblast, move outside the embryo to the yolk sac, and then migrate from the yolk sac to the early gonad (genital ridges). After genital ridges are colonized by PGC they are denominated primordial gonads (review by van den Hurk \& Zhao, 2005).

The migration and colonization of the gonads by PGC in females give rise to the oogonia, which, associated with somatic cells, undergo a phase of mitotic proliferation with an incomplete cytokinesis. In the developing ovary, the oogonia and pregranulosa somatic cells progressively organize into epithelial structures eventually recognized as ovarian follicles. However, before follicle formation, germ cells change from mitotic to meiotic and become primary oocytes, committed to follicle development (reviewed by Guigon \& Magre, 2006).

Still in fetal phase, all female germ cells reach the prophase of the first meiotic division, but instead of progressing to metaphase, they are kept arrested in the diplotene stage or germinal vesicle (GV). After birth, oocytes undergo some important processes for their growth and maturation, such as storage of mRNA, proteins, metabolic substrates and organelle reorganization. The primary oocytes, arrested in the first meiotic division, now become enveloped by a layer of flattened pregranulosa cells and a basal membrane to become primordial follicles (Picton, 2001).

Followed by the activation of growth, the primordial follicle is surrounded by a complete layer of cuboidal granulosa cells making it a primary follicle (Picton, 2001). During follicular growth, granulosa cells continue to proliferate and the theca layer is developed, which is required to produce androgens and to form the network of cells that support the vascular system of the growing follicle (Young \& McNeilly, 2010).

Primordial follicles remain 'dormant' in the ovaries until recruitment into the population of growing cells. Every day, a group of primordial follicles are recruited and start to grow based on the order in which they are initially formed. Consequently, certain primordial follicles are first transformed into primary follicles after a few days and others only after more than a year as in rodents, or after one to five decades later, as in women (van den Hurk \& Zhao, 2005).

Follicles are called primary follicles when the single layer of granulosa cells surrounding the oocyte becomes cuboidal. The transition of primordial follicles into primary follicles is slow and the diameter of its oocyte hardly changes. This process is associated with commitment 
and subsequent stages of follicular development, and it is independent of direct FSH action (Méduri et al., 2002).

Furthermore, when the follicle reaches several layers of granulosa cells, it starts forming the antrum, and the granulosa cells differentiate into two compartments: the mural cells, which internally surround the basal membrane, and the cumulus oophorus cells (CCs), that are closely associated with the oocyte. This structure forms the socalled cumulus-oocyte complex (COC) and its intricate interaction confers the oocyte with the competence to resume meiosis and be fertilized (Hyttel et al., 2010; Picton, 2001).

Bidirectional communication between oocytes and somatic cells

The granulosa cells have clearly established roles to support oocyte growth and the acquisition of developmental competence (Brower \& Schultz, 1982), but also participate in the control of meiosis progression (Eppig, 1991), and in the modulation of global transcriptional activity and chromatin remodeling in the oocyte (De La Fuente \& Eppig, 2001).

In recent years, researchers have focused on the understanding how the oocyte can influence granulosa cells through the so-called oocyte derived paracrine factors (ODPFs). Among them, the main players are the proteins of the transforming growth factor $\beta$ (TGF- $\beta$ ) superfamily, such as the growth differentiation factor 9 (GDF9) and the bone morphogenetic protein 15 (BMP15). Fibroblast growth factors (FGFs) are also secreted by oocytes and are reported to regulate granulosa cell development and function cooperatively with TGF- $\beta$ proteins (reviewed by Emori \& Sugiura, 2014).

Especially within antral follicles, ODPFs guide the differentiation and maintenance of granulosa and CCs (Eppig et al., 1997). In addition, ODPFs can stimulate growth and apoptosis (Gilchrist et al., 2001), energy metabolism (Sugiura et al., 2005; Sutton et al., 2003; Sutton-McDowall et al., 2010), sterol biosynthesis (Su et al., 2008) and the CCs expansion (Elvin et al., 1999; Varani et al., 2002). Thus, the oocyte can affect the functions of the CCs for their own benefit, since the oocyte is not able to produce all the substrates required for its maturation. To ensure an effective development, oocyte and cumulus/granulosa cells must communicate through a perfectly orchestrated signaling system.

One mechanisms of bidirectional communication between the CCs and oocyte is through the gap junctional communication (GJC). Gap junctions (GJ) are specialized membrane proteins occurring in points of very close contact between both cells. They consist of arrays of intercellular channels that allow direct sharing of small (less than $1 \mathrm{kD}$ ) molecules between the cells (Harris, 2001). Indeed, many of the molecules are known to be transferred from granulosa cells to the growing oocyte via GJC, e.g., amino acids, glucose, and ribonucleotides (Eppig et al., 2005; Sugiura et al., 2005). GJ are comprised of connexins, a homologous family of more than 20 proteins. The connexin 43 (Cx43) is predominantly expressed by cumulus/granulosa cells whereas $\mathrm{C} \times 37$ seems to be the only connexin connecting oocyte to the granulosa cells (Juneja et al., 1999), and the loss of Cx37 expression is detrimental to the oocyte-granulosa communication (Simon et al., 1997).

Macaulay et al. $(2014,2016)$ demonstrated by confocal and transmission electron microscopy, in combination with transcript detection, that somatic cells contribute to the maternal reserves of oocytes, including mRNA and long noncoding RNA. This communication is performed by transzonal projections (TZPs). These recent discoveries refined our understanding of the small molecule transport mechanism (GJC/TZP) synthesized by cumulus cells, which are transferred into the ooplasm.

Recently, a new mechanism of cell communication within the ovarian follicle was demonstrated; this mechanism is performed by extracellular vesicles (EVs). Initially, EVs were described in ovarian follicular fluid of mares using flow cytometer and transmission electron microscopy techniques (da Silveira et al., 2012). These EVs are lipid bilayer structures secreted by many cell types into the extracellular fluid, serving as a vehicle for membrane and cytosolic proteins, lipids, and RNA (Raposo \& Stoorvogel, 2013). Several articles identified miRNAs in bovine (Miles et al., 2012), equine (da Silveira et al., 2012) and human (Santonocito et al., 2014) follicular fluid, suggesting EVs as a potential mediator of cell-to-cell communication, impacting oocyte and follicle growth (reviewed by da Silveira et al., 2015).

\section{Cyclic nucleotides and maturation control}

Other important molecules that also use the GJC/TZP system to move around between CCs and oocyte are the cyclic nucleotides. Among those, we should highlight the adenosine $3^{\prime}, 5^{\prime}$-cyclic monophosphate (cAMP). This second messenger acts mostly in the phosphorylation of the cAMPdependent protein kinase A (PKA), leading to the activation of various cellular pathways. The cAMP is synthesized from adenosine triphosphate (ATP) by adenylate cyclase (AC), following the dissociation of the stimulatory-G (Gs) protein from specific classes of G-protein-coupled receptors (Wright et al., 2015). Variation in the intraoocyte concentration of cAMP can modulate the resumption of meiosis. Optimum concentration of CAMP maintains PKA active, which inhibits the maturation-promoting factor (MPF) and keeps the oocyte arrested at the GV stage (Sirard et al., 1998).

Another cyclic nucleotide, the cyclic guanosine monophosphate (cGMP), also plays its role in controlling meiotic arrest/resumption. cGMP is synthesized via different pathways, such as through nitric oxide (NO), bicarbonate, natriuretic peptides (NPPA, NPPB and NPPC), guanylins, uroguanylins and guanylyl cyclase activating proteins (GCAPs); those guanylin molecules can activate various enzymes, e.g., guanyl, adenylyl cyclases and guanylate, which act in the catalytic conversion of guanosine triphosphate (GTP) into cGMP and pyrophosphate (Potter, 2011).

Like CAMP, the cGMP molecules participate in protein kinase phosphorylation (cGMP-dependent protein kinase, PKG) and influence the activity of several phosphodiesterases (PDEs). The PDEs are intracellular enzymes that catalyze the hydrolysis of the cyclic phosphate bond into CAMP and CGMP to generate the inactive products $5^{\prime}$-AMP and $5^{\prime}$ GMP (Francis et al., 2011). The PDEs are classified into 11 families according to their affinity, although each family can have multiple isoforms (Francis et al., 2011). PDE activities can be of short or long term, and are modulated by signals including hormones, neurotransmitters, cytokines, light, and oxidative influences. The concentration of nucleotides (CAMP and CGMP) is controlled by the balance between their synthesis and degradation, which is carried out by the PDEs themselves (reviewed by Francis et al., 2011).

PDEs decrease CAMP concentration in immature oocytes to allow for meiosis resumption and, consequently, the onset of oocyte maturation (Sadler \& Maller, 1989). Tsafriri et al. (1996) reported that the location of PDE3A is restricted to the oocyte and they showed an effectively inhibition of spontaneous meiosis resumption in vitro using specific inhibitors. Additionally, Norris et al. (2009) demonstrated that CGMP synthesized by CCs moves across GJ/TZP to the oocyte and inhibit cAMP degradation by PDE3A. This process assures that the CAMP concentration, 
demanded by the GV-arrest, be maintained at optimum levels.

During the normal reproductive cycle, a surge of $\mathrm{LH}$ induces oocyte maturation and ovulation (Richards et al., 2002). Triggered by $\mathrm{LH}$, a receptor coupled to $\mathrm{G}$ protein is activated in the theca and granulosa cells (Breen et al., 2013; Gudermann et al., 1992; Rajagopalan-Gupta et al., 1998), inducing a rapid reduction in follicle cGMP, which is diffused out of the oocyte through GJ/TZP (Shuhaibar et al., 2015). Simultaneously, LH-induced phosphorylation and activation of PDE5 leads to decreasing levels of cGMP and relieves the inhibition of PDE3A in the oocyte, lowering CAMP content and allowing meiosis to resume (Egbert et al., 2016).

Knowledge of the physiology involved in oocyte meiotic arrest/resumption and maturation has enabled the development and improvement of techniques for the in vitro maturation (IVM) of oocytes. The IVM of mammalian oocytes is an essential tool for the basic or applied aspects of assisted reproductive technology (ART) such as developmental biology, in vitro production (IVP) of embryos, cloning, stem cells and embryology (Smitz et al., 2011). However, the efficiency of IVM is still low when compared to in vivo maturation, which limits its application in ART (Gilchrist, 2011). Drawbacks of IVM include decreased preimplantation embryo development, low pregnancy rates and poor live birth index (Child et al., 2002; Eppig et al., 2009). This is probably caused by the inefficiency of the oocyte to avoid the drastic decrease in CAMP concentration when removed from the follicular environment during ART procedures (Luciano et al., 2004; Mattioli et al., 1994). This spontaneous resumption of oocyte meiosis causes incomplete cytoplasmic maturation, and the asynchrony between cytoplasmic and nuclear maturation, affects oocyte development and embryo quality (Blondin et al., 1997; Gilchrist \& Thompson, 2007; Lonergan et al., 2003).

Several authors have reported reversible inhibition of spontaneous meiotic resumption by pharmacological methods and most of these strategies are described in the following section of this review.

\section{Pharmacological approaches to modulate cyclic nucleotides during in vitro maturation}

Reversible inhibition of meiotic resumption by pharmacological methods have been long tried by many researchers, but results on the subsequent developmental competence is variable and often lower than in COCs cultured without inhibition (Fulka et al., 1991; Lonergan et al., 1997; Avery et al., 1998; Kubelka et al., 2000; Mermillod et al., 2000). In addition, pharmacological manipulations may, occasionally, affect oocytes and embryos at the ultrastructural level as well (Faerge et al., 2001; Lonergan et al., 2003; Nogueira et al., 2003, 2005; Vanhoutte et al., 2007).

In mammalian oocytes, among the pharmacological approaches used for in vitro maturation to maintain meiotic arrest - or at least to retard meiotic spontaneous resumption - we have the cAMP modulators: dbcAMP (Sirard \& First, 1988) and 8-bromo-cAMP (Chen et al., 2009), phosphodiesterase inhibitors: specific inhibitors of the PDE3, such as, cilostamide (Gharibi et al., 2013; Mayes \& Sirard, 2002; Shu et al., 2008; Vanhoutte et al., 2008) and milrinone (Mayes \& Sirard, 2002; Thomas et al., 2002, 2004b), PDE4: rolipram (Mayes \& Sirard, 2002; Thomas et al., 2002, 2004b) and PDE8: dipyridamole (Sasseville et al., 2009), nonspecific inhibitor: IBMX (Albuz et al., 2010; Rose et al., 2013; Thomas et al., 2002) and stimulators of adenylate cyclase: forskolin (Albuz et al., 2010; Richani et al., 2014; Shu et al., 2008; Zeng et al.,
2014) and iAC (Aktas et al., 1995; Guixue et al., 2001; Luciano et al., 2004).

The overall objective of these pharmacological manipulations is to avoid premature nuclear maturation in vitro by means of maintaining higher concentration of CAMP within the ooplasm. This should provide enough time for the COC to synchronize nuclear and cytoplasmic maturation, as similar as possible to the in vivo event that would allegedly result in more competent oocytes and embryo (Thomas et al., 2004a). Unsurprisingly, the mechanism of synthesis and hydrolysis of cGMP is one of the main targets of pharmacological strategies to control oocyte maturation.

Nakamura et al. (2002) described an important role of inducible nitric oxide (NO) synthase (iNOS)/NO/cGMP in the control of oocyte maturation in rats. This technique uses a NO donor (S-nitroso-L-acetyl penicillamine - SNAP) for 5 hours to reversibly prevent GV breakdown. This discovery paved the way for many other studies that also reported the activation of this pathway in several mammalian species, including rats (Sela-Abramovich et al., 2008), mice (Norris et al., 2009), pigs (Chmelíková et al., 2010; Tichovská et al., 2011) and bovines (Pires et al., 2009; Sasseville et al., 2008; Schwarz et al., 2008, 2010).

New approaches for modifying IVM and improve developmental competence take into consideration the knowledge from cGMP/CAMP and the use of dynamic systems. Furthermore, non-pharmacological strategies are trending since the 2010 paper from Dr. John Eppig, describing the role of the granulosa cell ligand natriuretic peptide precursor type C (NPPC) and its receptor NPR2 in maintaining meiotic arrest in mice oocytes.

Novel systems of in vitro maturation and their impacts in the resulting embryo

Based on the significant advances of the mechanisms that control oocyte maturation and their interaction with the CCs, new paths were opened to improve the IVM technique. One of which is the use of dynamic in vitro systems to improve embryo quality and quantity, the socalled prematuration or pre-IVM systems.

Interesting approaches for modifying IVM to improve developmental competence is the use of a two-step culture or pre-maturation systems, where during the initial step a medium that does not promote nuclear maturation is used (Albuz et al., 2010; Franciosi et al., 2014; Luciano et al., 2004; Oliveira e Silva et al., 2011; Ponderato et al., 2002). Among the systems that have been developed, the most promising are those that pharmacologically inhibit or retard meiotic resumption by elevating CAMP concentration in the oocyte while sustaining GJ communication functionality (Albuz et al., 2010; Luciano et al., 2004). It was previously reported that modulation of CAMP levels within mammalian COCs during IVM could substantially improve oocyte developmental competence in several species (Albuz et al., 2010; Funahashi et al., 1997; Luciano et al., 1999, 2004; Nogueira et al., 2003, 2006; Shu et al., 2008; Thomas et al., 2004b; Vanhoutte et al., 2009; Zeng et al., 2013; Figure 1).

In 2003, Shimada et al. (2003) investigated the formation of LH receptor in cumulus cells of swine COCs and, after its detection, a new two-step culture system was developed. In the first step, the COCs were cultured in medium supplemented with FSH and IBMX for 20h, followed by culture in medium supplemented with LH (second-step). This two-step system with FSH and 0.5 $\mathrm{mM}$ IBMX induced the expression of $\mathrm{LH}$ receptors in CCs, improved the rate of blastocyst formation and increased the number of cells in IVF blastocysts (Figure 1). 


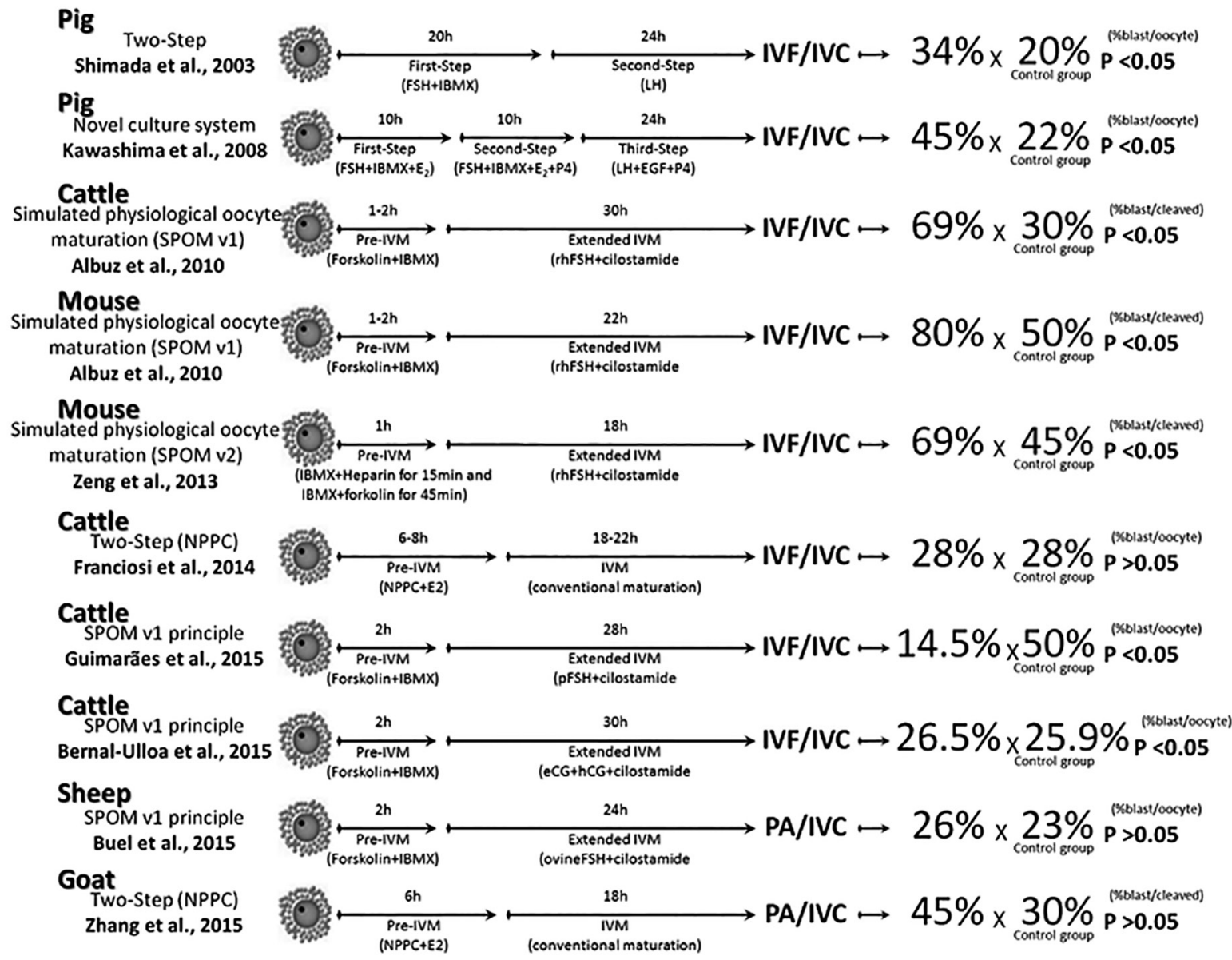

Figure 1. Summarized representation of different strategies used during in vitro maturation to modulate the intraoocyte concentration of cyclic nucleotides and improve embryo yield in several mammalian species (pigs, cattle, mice, sheep or goat). After each approach, there is a brief schematic description of the methods the authors used. The figure shows the rates of blastocyst in each treatment in comparison to their respective control group. Statistical significance is indicated by the $p$ value. Note that some authors calculate the in vitro performance by dividing the number of blastocyst by the number of oocytes and others by the number of cleaved embryos. IVF: in vitro fertilization; IVC: in vitro culture; PA: parthenogenetic activation.

To better understand the influence of hormones and growth factor production on the mechanisms controlling the in vivo maturation in pigs, Kawashima et al. (2008) updated the two-step system into a new one called "novel culture system - NCS". In the NCS design, COCs are recovered from small antral follicles ( $3-5 \mathrm{~mm}$ in diameter); first pre-IVM uses FSH, E2 and IBMX for $10 \mathrm{~h}$ to induce cell proliferation; second pre-IVM takes place with FSH, E2, IBMX and P4 for $10 \mathrm{~h}$ to suppress cell proliferation and induce LH receptor mRNA expression and finally, an IVM with LH, EGF and P4 for additional 24h (Figure 1). Using NCS system, Kawashima et al. (2008) reported the full expansion of porcine COCs, decreased number of cumulus cells in apoptotic process and, when oocytes obtained from NCS were used for IVF, the developmental competence to blastocyst was significantly improved when compared with the conventional culture system (FSH+LH for $48 \mathrm{~h}$ ), or with the two-step culture system (Funahashi et al., 1997; Shimada et al., 2003; Figure 1).

Early in the decade, Albuz et al. (2010) proposed a new IVM system. Their methodology was seeking to mimic the processes that occurred in the in vivo maturation; hence their system was called simulated physiological oocyte maturation (SPOM; Figure 1). This system consisted of a small pre-IVM (1-2h) where the adenylate cyclase was stimulated with forskolin, increasing CAMP levels and IBMX, a PDE inhibitor, to prevent hydrolysis of cyclic nucleotides (CAMP and CGMP), and after the pre-IVM, the COCs were subjected to an extended IVM for 24 hours, where the culture medium was supplemented with cilostamide (PDE3 inhibitor) and recombinant human (rh)-FSH. Results of the SPOM system were quite exciting, with rates of $69 \%$ of blastocysts per cleaved embryo. Later, the SPOM protocol was adapted to sheep oocytes and, even though no significant effect on blastocyst rates were achieved, there was an improvement in blastocyst quality observed by an increase in total cell number (Rose et al., 2013; Figure 1).

The promising results of the first version of the SPOM system (SPOMv1) greatly impacted ART research; still, the SPOM system was updated by their creators in subsequent studies. Zeng et al. (2013) used heparin during pre-MIV and removed the cilostamide from the extended IVM. This approach positively affected oocyte energy metabolism, oocyte meiotic maturation and embryo development (SPOMv2; Figure 1).

One year later, Zeng et al. (2014) tested the presence of rh-FSH during extended IVM (Figure 1). By now it seems that cilostamide in extended IVM phase is gone 
for good, and now the system is no longer called SPOM, but Prematuration System (or Pre-IVM system) instead. They reported successful results in IVP of mice embryos ( $\pm 70 \%$ of blastocysts per cleaved embryos), better quality in the expansion of CCs, reduction of abnormal spindles and a positive influence of Pre-IVM system in the glycolic metabolism of COCs (suggesting an effect of CAMP production predominantly on glycolytic activity).

Several laboratories and research groups around the world sought to repeat the success obtained by the SPOM or Pre-IVM system; however, most failed in doing so (BernalUlloa et al., 2016; Buell et al., 2015; Guimarães et al., 2015; Razza et al., 2015; Figure 1). Ulloa et al. (2015), using bovine oocytes cultured in SPOM system, produced a smaller number of blastocyst compared with the standard IVM. However, the pattern of DNA methylation of embryos produced in SPOM system was more similar to embryos produced in vivo. Also, Santiquet et al. (2014a) tested a pre-IVM treatment and could improve the developmental competence of oocytes, as demonstrated by increased embryo development. Additionally, pre-IVM performed with IBMX and forskolin in the Pre-IVM system can change ultrastructural characteristics of oocytes and blastocysts (Razza et al., 2015; unpublished data from our group).

With the strategy used in the SPOM system of performing a two-step culture with different drugs to induce different effects in CCs and oocytes during IVM, new drugs and signaling pathways have emerged as potential targets for research seeking to improve IVM and embryo production.

Earlier in this decade, a new model discovered that the binding of NPPC to its receptor (NPR2) in granulosa and CCS are the main cause for the modulation of cGMP levels (Zhang et al., 2010). Until now, studies relating the new mechanism of NPPC/NPR2/cGMP in maturation control have been reported in mice (Tsuji et al., 2012; Zhang et al., 2011), bovines (Franciosi et al., 2014), swine (Santiquet et al., 2014b; Zhang et al., 2014) and sheep (Zhang et al., 2015; Figure 1).

Using the NPPC during pre-IVM (8h) in bovine COCs, Franciosi et al. (2014) could successfully arrest meiosis resumption and extend the functional communication among oocytes and CCs through GJ. After IVF and embryo culture, the NPPC treatment in pre-IVM has also increased blastocyst cell number and hatching rates.

In a more recent approach of two-step maturation with caprine COCs, Zhang et al. (2015) used the NPPC and estradiol during pre-IVM ( $8 \mathrm{~h})$, followed by conventional IVM (18h). With this system, meiosis was effectively arrested in pre-IVM and the maturation rate was also increased after conventional IVM. They also increased embryo production and quality, evaluated by total cell number per blastocyst (Figure 1).

Conventionally, oocyte competence has been assessed by embryo morphology and blastocyst rates; however, these aspects alone do not provide sufficient information to fully endorse the IVM system efficiency. Several strategies are being used to study the quality of oocytes (before and after IVM) and embryos. Some of the most promising and approaches that focus on the identification of biomarkers.

\section{New perspectives and final considerations}

A few non-invasive strategies are already being used to predict oocyte competence to become a viable embryo, even before the oocyte is fertilized. These approaches aim to identify oocyte competence biomarkers mostly in cumulus cells. In this context, the morphology of CCs can be used to first categorize oocyte potential (de Loos et al., 1991) and then to compare the morphological data with CCs transcriptome (differentially expressed genes in CCs surrounding the good oocytes versus poor-quality oocytes). At present, many genes are identified as potential biomarkers (reviewed by Labrecque \& Sirard, 2014). Still, many research groups are working on the identification of miRNAs as biomarkers as well. Profiles of miRNAs isolated from EVs present in follicular fluid were described and associated with proper cytoplasmic oocyte maturation; hence, these miRNA profiles can be used to predict oocyte competence (Sohel et al., 2013).

The use of non-invasive strategies, such as analysis of follicular fluid and culture media (after culture) also appears to be quite useful on the search for molecular biomarkers for oocyte competence. The presence of cytokines and growth factors in follicular fluid is crucial for determining oocyte quality (reviewed by Dumesic et al., 2015). In this context, the metabolic characterization of the culture media, in which IVP embryos are kept for many hours, may represent an important non-invasive tool to either indicate possible predictive biomarkers of viability or to explain IVP outcome afterwards (Muñoz et al., 2014).

Lipid metabolism is induced in COCs during oocyte maturation and contributes to oocyte and embryo development (Gardner \& Harvey, 2015). Specific fatty acids have distinct effects on oocyte maturation. In general, saturated fatty acids (palmitic acid and stearic acid) are elevated in follicular fluid and, in some metabolic contexts, are detrimental, while the presence of unsaturated non-esterified fatty acids (oleic acid and linoleic acid) can counteract these detrimental effects and promote developmental competence (reviwed by Dunning et al., 2014). Thus, in vitro oocyte and embryo development may be optimized through the provision of appropriate energy substrates and essential co-factors during ART in domestic animals and subfertility women.

Despite the large number of publications in the field we still have a long way to go to deeply understand and manipulate the mechanisms controlling oocyte maturation. Overcoming these gaps may allow us to improve ART results. Therefore, it is necessary to design studies aiming at finding effective biomarkers for oocyte competence. The field of the OMICs seems to be quite promising, especially regarding the new findings in transcriptomics, proteomics and lipidomics in oocytes, CCs, embryos and in the EVs within the follicular fluid. Future studies on this subject might enable the design of more complex, defined and efficient culture conditions for oocytes to be fully matured and able to generate optimum IVP embryos.

\section{ACKNOWLEDGEMENTS}

We acknowledge the São Paulo Research Foundation (FAPESP) for funding (2012/50533-2 and 2013/05083-1) and fellowships for RCB (2014/25072-7), EMR (12/23409-9) and $\operatorname{EMP}(13 / 07730-4)$.

\section{CONFLICT OF INTERESTS}

No conflict of interests has been declared.

\section{Corresponding author:}

Ramon Cesar Botigelli

Multi-user laboratory Phytomedicine

Pharmacology and Biotechnology (FitoFarmaTec)

Institute of Bioscience, University of São Paulo State Botucatu - SP, Brazil

E-mail: ramonbotigelli@gmail.com

\section{REFERENCES}

Aktas $\mathrm{H}$, Wheeler MB, Rosenkrans CF Jr, First NL, Leibfried-Rutledge ML. Maintenance of bovine oocytes in prophase of meiosis I by high [CAMP]i. J Reprod Fertil. 1995;105:227-35. PMID: 8568765 DOI: http://dx.doi.org/10.1530/jrf.0.1050227 
Albuz FK, Sasseville M, Lane M, Armstrong DT, Thompson JG, Gilchrist RB. Simulated physiological oocyte maturation (SPOM): a novel in vitro maturation system that substantially improves embryo yield and pregnancy outcomes. Hum Reprod. 2010;25:2999-3011. PMID: 20870682 DOI: http://dx.doi.org/10.1093/humrep/deq246

Avery B, Hay-Schmidt A, Hyttel P, Greve T. Embryo development, oocyte morphology, and kinetics of meiotic maturation in bovine oocytes exposed to 6-dimethylaminopurine prior to in vitro maturation. Mol Reprod Dev. 1998;50:334-44. PMID: 9621310 DOI: http://dx.doi.org/10.1002/(SICI)10982795(199807)50:3<334: :AID-MRD10>3.0.CO;2-4

Bernal-Ulloa SM, Heinzmann J, Herrmann D, Hadeler KG, Aldag $P$, Winkler $S$, Pache $D$, Baulain $U$, Lucas-Hahn $A$, Niemann H. Cyclic AMP Affects Oocyte Maturation and Embryo Development in Prepubertal and Adult Cattle. PLoS One. 2016;11:e0150264. PMID: 26926596 DOI: http://dx.doi.org/10.1371/journal.pone.0150264

Blondin P, Coenen K, Guilbault LA, Sirard MA. In vitro production of bovine embryos: developmental competence is acquired before maturation. Theriogenology. 1997;47:1061-75. PMID: 16728056 DOI: http://dx.doi.org/10.1016/S0093-691X(97)00063-0

Breen SM, Andric N, Ping T, Xie F, Offermans S, Gossen JA, Ascoli M. Ovulation involves the luteinizing hormone-dependent activation of $\mathrm{G}(\mathrm{q} / 11)$ in granulosa cells. Mol Endocrinol. 2013;27:1483-91. PMID: 23836924 DOI: http://dx.doi.org/10.1210/me.2013-1130

Brower PT, Schultz RM. Intercellular communication between granulosa cells and mouse oocytes: existence and possible nutritional role during oocyte growth. Dev Biol. 1982;90:144-53. PMID: 7199496 DOI: http://dx.doi.org/10.1016/0012-1606(82)90219-6

Buell M, Chitwood JL, Ross PJ. cAMP modulation during sheep in vitro oocyte maturation delays progression of meiosis without affecting oocyte parthenogenetic developmental competence. Anim Reprod Sci. 2015;154:16-24. PMID: 25595334 DOI: http://dx.doi.org/10.1016/j.anireprosci.2014.12.012

Chen J, Chi MM, Moley KH, Downs SM. CAMP pulsing of denuded mouse oocytes increases meiotic resumption via activation of AMP-activated protein kinase. Reproduction. 2009;138:759-70. PMID: 19700529 DOI: http://dx.doi.org/10.1530/REP-08-0535

Child TJ, Phillips SJ, Abdul-Jalil AK, Gulekli B, Tan SL. A comparison of in vitro maturation and in vitro fertilization for women with polycystic ovaries. Obstet Gynecol. 2002;100:665-70. PMID: 12383531 DOI: http://dx.doi.org/10.1097/00006250-200210000-00009

Chmelíková E, Jeseta M, Sedmíková M, Petr J, Tumová L, Kott T, Lipovová P, Jílek F. Nitric oxide synthase isoforms and the effect of their inhibition on meiotic maturation of porcine oocytes. Zygote. 2010;18:235-44. PMID: 20109267 DOI: http://dx.doi.org/10.1017/S0967199409990268

da Silveira JC, Veeramachaneni DN, Winger QA, Carnevale EM, Bouma GJ. Cell-secreted vesicles in equine ovarian follicular fluid contain miRNAs and proteins: a possible new form of cell communication within the ovarian follicle. Biol Reprod. 2012;86:71. PMID: 22116803 DOI: http://dx.doi.org/10.1095/biolreprod.111.093252 da Silveira JC, de Andrade GM, Nogueira MF, Meirelles FV, Perecin F. Involvement of miRNAs and Cell-Secreted Vesicles in Mammalian Ovarian Antral Follicle Development. Reprod Sci. 2015;22:1474-83. PMID: 25736328 DOI: http://dx.doi.org/10.1177/1933719115574344

De La Fuente $\mathrm{R}$, Eppig JJ. Transcriptional activity of the mouse oocyte genome: companion granulosa cells modulate transcription and chromatin remodeling. Dev Biol. 2001;229:224-36. PMID: 11133166 DOI: http://dx.doi.org/10.1006/dbio.2000.9947

de Loos F, Kastrop P, Van Maurik P, Van Beneden TH, Kruip TA. Heterologous cell contacts and metabolic coupling in bovine cumulus oocyte complexes. Mol Reprod Dev. 1991;28:255-9. PMID: 2015084 DOI: http://dx.doi.org/10.1002/mrd.1080280307

Dunning KR, Russell DL, Robker RL. Lipids and oocyte developmental competence: the role of fatty acids and B-oxidation. Reproduction. 2014;148:R15-27. PMID: 24760880 DOI: http://dx.doi.org/10.1530/REP-13-0251

Dumesic DA, Meldrum DR, Katz-Jaffe MG, Krisher RL, Schoolcraft WB. Oocyte environment: follicular fluid and cumulus cells are critical for oocyte health. Fertil Steril. 2015;103:303-16. PMID: 25497448 DOI: http://dx.doi.org/10.1016/j.fertnstert.2014.11.015

Egbert JR, Uliasz TF, Shuhaibar LC, Geerts A, Wunder F, Kleiman RJ, Humphrey JM, Lampe PD, Artemyev NO, Rybalkin SD, Beavo JA, Movsesian MA, Jaffe LA. Luteinizing Hormone Causes Phosphorylation and Activation of the cGMP Phosphodiesterase PDE5 in Rat Ovarian Follicles, Contributing, Together with PDE1 Activity, to the Resumption of Meiosis. Biol Reprod. 2016;94:110. PMID: 27009040 DOI: http://dx.doi.org/10.1095/biolreprod.115.135897

Elvin JA, Yan C, Wang P, Nishimori K, Matzuk MM. Molecular characterization of the follicle defects in the growth differentiation factor 9-deficient ovary. Mol Endocrinol. 1999;13:1018-34. PMID: 10379899 DOI: http://dx.doi.org/10.1210/mend.13.6.0309

Emori C, Sugiura K. Role of oocyte-derived paracrine factors in follicular development. Anim Sci J. 2014;85:627-33. PMID: 24717179 DOI: http://dx.doi.org/10.1111/asj.12200

Eppig JJ. Intercommunication between mammalian oocytes and companion somatic cells. Bioessays. 1991;13:569-74. PMID: 1772412 DOI: http://dx.doi.org/10.1002/bies.950131105

Eppig JJ, Chesnel F, Hirao Y, O'Brien MJ, Pendola FL, Watanabe $\mathrm{S}$, Wigglesworth K. Oocyte control of granulosa cell development: how and why. Hum Reprod. 1997;12:127-32. PMID: 9433969

Eppig JJ, Pendola FL, Wigglesworth K, Pendola JK. Mouse oocytes regulate metabolic cooperativity between granulosa cells and oocytes: amino acid transport. Biol Reprod. 2005;73:351-7. PMID: 15843493 DOI: http://dx.doi.org/10.1095/biolreprod.105.041798

Eppig JJ, O'Brien MJ, Wigglesworth K, Nicholson A, Zhang W, King BA. Effect of in vitro maturation of mouse oocytes on the health and lifespan of adult offspring. Hum Reprod. 2009;24:922-8. PMID: 19151027 DOI: http://dx.doi.org/10.1093/humrep/den466 
Faerge I, Mayes M, Hyttel P, Sirard MA. Nuclear ultrastructure in bovine oocytes after inhibition of meiosis by chemical and biological inhibitors. Mol Reprod Dev. 2001;59:459-67. PMID: 11468783 DOI: http://dx.doi.org/10.1002/mrd.1053

Franciosi F, Coticchio G, Lodde V, Tessaro I, Modina SC, Fadini R, Dal Canto M, Renzini MM, Albertini DF, Luciano AM. Natriuretic peptide precursor $C$ delays meiotic resumption and sustains gap junction-mediated communication in bovine cumulus-enclosed oocytes. Biol Reprod. 2014;91:61. PMID: 25078681 DOI: http://dx.doi.org/10.1095/biolreprod.114.118869

Francis SH, Blount MA, Corbin JD. Mammalian cyclic nucleotide phosphodiesterases: molecular mechanisms and physiological functions. Physiol Rev. 2011;91:651-90. PMID: 21527734 DOI: http://dx.doi.org/10.1152/physrev.00030.2010

Fulka J Jr, Leibfried-Rutledge ML, First NL. Effect of 6-dimethylaminopurine on germinal vesicle breakdown of bovine oocytes. Mol Reprod Dev. 1991;29:379-84. PMID: 1888517 DOI: http://dx.doi.org/10.1002/mrd.1080290410

Funahashi H, Cantley TC, Day BN. Synchronization of meiosis in porcine oocytes by exposure to dibutyryl cyclic adenosine monophosphate improves developmental competence following in vitro fertilization. Biol Reprod. 1997;57:49-53. PMID: 9209079 DOI: http://dx.doi.org/10.1095/biolreprod57.1.49

Gardner DK, Harvey AJ. Blastocyst metabolism. Reprod Fertil Dev. 2015;27:638-54. PMID: 25751298 DOI: http://dx.doi.org/10.1071/RD14421

Gharibi Sh, Hajian M, Ostadhosseini S, Hosseini SM, Forouzanfar M, Nasr-Esfahani MH. Effect of phosphodiesterase type 3 inhibitor on nuclear maturation and in vitro development of ovine oocytes. Theriogenology. 2013;80:302-12. PMID: 23683693 DOI: http://dx.doi.org/10.1016/j.theriogenology.2013.04.012

Gilchrist RB. Recent insights into oocyte-follicle cell interactions provide opportunities for the development of new approaches to in vitro maturation. Reprod Fertil Dev. 2011;23:23-31. PMID: 21366977 DOI: http://dx.doi.org/10.1071/RD10225

Gilchrist RB, Ritter LJ, Armstrong DT. Mouse oocyte mitogenicactivity is developmentally coordinated throughout folliculogenesis and meiotic maturation. Dev Biol. 2001;240:289-98. PMID: 11784064 DOI: http://dx.doi.org/10.1006/dbio.2001.0451

Gilchrist RB, Thompson JG. Oocyte maturation: emerging concepts and technologies to improve developmental potential in vitro. Theriogenology. 2007;67:6-15. PMID: 17092551 DOI: http://dx.doi.org/10.1016/j.theriogenology.2006.09.027

Gudermann T, Birnbaumer M, Birnbaumer L. Evidence for dual coupling of the murine luteinizing hormone receptor to adenyIyl cyclase and phosphoinositide breakdown and Ca2+ mobilization. Studies with the cloned murine luteinizing hormone receptor expressed in L cells. J Biol Chem. 1992;267:447988. PMID: 1311310

Guigon CJ, Magre S. Contribution of germ cells to the differentiation and maturation of the ovary: insights from models of germ cell depletion. Biol Reprod. 2006;74:450-8. PMID: 16339043 DOI: http://dx.doi.org/10.1095/biolreprod.105.047134

Guimarães AL, Pereira SA, Leme LO, Dode MA. Evaluation of the simulated physiological oocyte maturation system for improving bovine in vitro embryo production. Theriogenology. 2015;83:52-7. PMID: 25447152 DOI: http://dx.doi.org/10.1016/j.theriogenology.2014.07.042
Guixue Z, Luciano AM, Coenen K, Gandolfi F, Sirard MA. The influence of CAMP before or during bovine oocyte maturation on embryonic developmental competence. Theriogenology. 2001;55:1733-43. PMID: 11393223 DOI: http://dx.doi.org/10.1016/S0093-691X(01)00516-7

Harris AL. Emerging issues of connexin channels: biophysics fills the gap. Q Rev Biophys. 2001;34:325-472. PMID: 11838236 DOI: https://doi.org/10.1017/S0033583501003705

Hyttel P, Sinowatz F, Vejlsted M, Betteridge K. Essentials of Domestic Animal Embryology. Philadelphia: Saunders; 2010.

Juneja SC, Barr KJ, Enders GC, Kidder GM. Defects in the germ line and gonads of mice lacking connexin43. Biol Reprod. 1999;60:1263-70. PMID: 10208994 DOI: http://dx.doi.org/10.1095/biolreprod60.5.1263

Kawashima I, Okazaki T, Noma N, Nishibori M, Yamashita Y, Shimada M. Sequential exposure of porcine cumulus cells to FSH and/or LH is critical for appropriate expression of steroidogenic and ovulation-related genes that impact oocyte maturation in vivo and in vitro. Reproduction. 2008;136:9-21. PMID: 18456902 DOI: http://dx.doi.org/10.1530/REP-08-0074

Kubelka M, Motlík J, Schultz RM, Pavlok A. Butyrolactone I reversibly inhibits meiotic maturation of bovine oocytes, Without influencing chromosome condensation activity. Biol Reprod. 2000;62:292-302. PMID: 10642565 DOI: http://dx.doi.org/10.1095/biolreprod62.2.292

Labrecque R, Sirard MA. The study of mammalian oocyte competence by transcriptome analysis: progress and challenges. Mol Hum Reprod. 2014;20:103-16. PMID: 24233546 DOI: http://dx.doi.org/10.1093/molehr/gat082

Lonergan P, Khatir H, Carolan C, Mermillod P. Bovine blastocyst production in vitro after inhibition of oocyte meiotic resumption for 24 h. J Reprod Fertil. 1997; 109:355-65. PMID: 9155746 DOI: http://dx.doi.org/10.1530/jrf.0.1090355

Lonergan P, Rizos D, Gutierrez-Adan A, Fair T, Boland MP. Oocyte and embryo quality: effect of origin, culture conditions and gene expression patterns. Reprod Domest Anim. 2003;38:259-67. PMID: 12887565 DOI: http://dx.doi.org/10.1046/j.1439-0531.2003.00437.x

Luciano AM, Modina S, Vassena R, Milanesi E, Lauria A, Gandolfi F. Role of intracellular cyclic adenosine 3',5'-monophosphate concentration and oocyte-cumulus cells communications on the acquisition of the developmental competence during in vitro maturation of bovine oocyte. Biol Reprod. 2004;70:465-72. PMID: 14568913 DOI: http://dx.doi.org/10.1095/biolreprod.103.020644

Luciano AM, Pocar P, Milanesi E, Modina S, Rieger D, Lauria A, Gandolfi F. Effect of different levels of intracellular CAMP on the in vitro maturation of cattle oocytes and their subsequent development following in vitro fertilization. Mol Reprod Dev. 1999;54:86-91. DOI: https://doi. org/10.1002/(SICI)1098-2795(199909)54:1<86: :AIDMRD13>3.0.CO;2-C

Macaulay AD, Gilbert I, Caballero J, Barreto R, Fournier E, Tossou P, Sirard MA, Clarke HJ, Khandjian ÉW, Richard FJ, Hyttel P, Robert C. The gametic synapse: RNA transfer to the bovine oocyte. Biol Reprod. 2014;91:90. PMID: 25143353 DOI: http://dx.doi.org/10.1095/biolreprod.114.119867 
Macaulay AD, Gilbert I, Scantland S, Fournier E, Ashkar $F$, Bastien A, Saadi HA, Gagné D, Sirard MA, Khandjian EW, Richard FJ, Hyttel P, Robert C. Cumulus Cell Transcripts Transit to the Bovine Oocyte in Preparation for Maturation. Biol Reprod. 2016;94:16. PMID: 26586844 DOI: http://dx.doi.org/10.1095/biolreprod.114.127571

Mattioli M, Galeati G, Barboni B, Seren E. Concentration of cyclic AMP during the maturation of pig oocytes in vivo and in vitro. J Reprod Fertil. 1994;100:403-9. PMID: 8021856 DOI: http://dx.doi.org/10.1530/jrf.0.1000403

Mayes MA, Sirard MA. Effect of type 3 and type 4 phosphodiesterase inhibitors on the maintenance of bovine oocytes in meioticarrest. BiolReprod. 2002;66:180-4. PMID: 11751280 DOI: http://dx.doi.org/10.1095/biolreprod66.1.180

Méduri G, Charnaux N, Driancourt MA, Combettes L, Granet $P$, Vannier B, Loosfelt H, Milgrom E. Follicle-stimulating hormone receptors in oocytes? J Clin Endocrinol Metab. 2002;97:2266-76. PMID: 11994374 DOI: http://dx.doi.org/10.1210/jc.87.5.2266

Mermillod P, Tomanek M, Marchal R, Meijer L. High developmental competence of cattle oocytes maintained at the germinal vesicle stage for 24 hours in culture by specific inhibition of MPF kinase activity. Mol Reprod Dev. 2000;55:89-95. DOI: https:// doi.org/10.1002/(SICI)1098-2795(200001)55:1<89::AIDMRD12>3.0.CO;2-M

Miles JR, McDaneld TG, Wiedmann RT, Cushman RA, Echternkamp SE, Vallet JL, Smith TP. MicroRNA expression profile in bovine cumulus-oocyte complexes: possible role of let-7 and miR-106a in the development of bovine oocytes. Anim Reprod Sci. 2012;130:16-26. PMID: 22269106 DOI: http://dx.doi.org/10.1016/j.anireprosci.2011.12.021

Muñoz M, Uyar A, Correia E, Díez C, Fernandez-Gonzalez A, Caamaño JN, Martínez-Bello D, Trigal B, Humblot P, Ponsart C, Guyader-Joly C, Carrocera S, Martin D, Marquant Le Guienne B, Seli E, Gomez E. Prediction of pregnancy viability in bovine in vitro-produced embryos and recipient plasma with Fourier transform infrared spectroscopy. J Dairy Sci. 2014;97:5497-507. PMID: 24997663 DOI: http://dx.doi.org/10.3168/jds.2014-8067

Nakamura Y, Yamagata Y, Sugino N, Takayama $H$, Kato $\mathrm{H}$. Nitric oxide inhibits oocyte meiotic maturation. Biol Reprod. 2002;67:1588-92. PMID: 12390892 DOI: http://dx.doi.org/10.1095/biolreprod.102.005264

Nogueira D, Cortvrindt R, De Matos DG, Vanhoutte L, Smitz J. Effect of phosphodiesterase type 3 inhibitor on developmental competence of immature mouse oocytes in vitro. Biol Reprod. 2003;69:2045-52. PMID: 12930710 DOI: http://dx.doi.org/10.1095/biolreprod.103.021105

Nogueira D, Cortvrindt R, Everaerdt B, Smitz J. Effects of long-term in vitro exposure to phosphodiesterase type-3 inhibitors on follicle and oocyte development. Reproduction. 2005;130:177-86. PMID: 16049155 DOI: http://dx.doi.org/10.1095/biolreprod.105.040485

Nogueira D, Ron-EI R, Friedler S, Schachter M, Raziel A, Cortvrindt R, Smitz J. Meiotic arrest in vitro by phosphodiesterase 3-inhibitor enhances maturation capacity of human oocytes and allows subsequent embryonic development. Biol Reprod. 2006;74:177-84. PMID: 16207840 DOI: http://dx.doi.org/10.1095/biolreprod.105.040485
Norris RP, Ratzan WJ, Freudzon M, Mehlmann LM, Krall J, Movsesian MA, Wang $\mathrm{H}$, Ke $\mathrm{H}$, Nikolaev VO, Jaffe LA. Cyclic GMP from the surrounding somatic cells regulates cyclic AMP and meiosis in the mouse oocyte. Development. 2009;136:1869-78. PMID: 19429786 DOI: http://dx.doi.org/10.1242/dev.035238

Oliveira e Silva I, Vasconcelos RB, Caetano JV, Gulart LV, Camargo LS, Báo SN, Rosa e Silva AA. Induction of reversible meiosis arrest of bovine oocytes using a two-step procedure under defined and nondefined conditions. Theriogenology. 2011;75:1115-24. PMID: 21220166 DOI: http://dx.doi.org/10.1016/j.theriogenology.2010.11.021

Picton HM. Activation of follicle development: the primordial follicle. Theriogenology. 2001;55:1193-210. PMID: 11327680 DOI: http://dx.doi.org/10.1016/S0093-691X(01)00478-2

Pires PR, Santos NP, Adona PR, Natori MM, Schwarz $K R$, de Bem $T H$, Leal $C L$. Endothelial and inducible nitric oxide synthases in oocytes of cattle. Anim Reprod Sci. 2009;116:233-43. PMID: 19327921 DOI: http://dx.doi.org/10.1016/j.anireprosci.2009.02.019

Ponderato N, Crotti G, Turini P, Duchi R, Galli C, Lazzari G. Embryonic and foetal development of bovine oocytes treated with a combination of butyrolactone I and roscovitine in an enriched medium prior to IVM and IVF. Mol Reprod Dev. 2002;62:513-8. PMID: 12112585 DOI: http://dx.doi.org/10.1002/mrd.10134

Potter LR. Guanylyl cyclase structure, function and regulation. Cell Signal. 2011;23:1921-6. PMID: 21914472 DOI: http://dx.doi.org/10.1016/j.cellsig.2011.09.001

Rajagopalan-Gupta RM, Lamm ML, Mukherjee S, Rasenick MM, Hunzicker-Dunn M. Luteinizing hormone/choriogonadotropin receptor-mediated activation of heterotrimeric guanine nucleotide binding proteins in ovarian follicular membranes. Endocrinology. 1998;139:4547-55. PMID: 28200179 DOI: http://dx.doi.org/10.1210/en.139.11.4547

Raposo G, Stoorvogel W. Extracellular vesicles: exosomes, microvesicles, and friends. J Cell Biol. 2013;200:373-83. PMID: 23420871 DOI: http://dx.doi.org/10.1083/jcb.201211138

Razza $E$, Pedersen $H$, Stroebech L, Machado $M$, Nogueira M, Kadarmideen H, Callesen H, Hyttel P. 192 Prematuration of bovine cumulus-oocyte complexes with cylic adenosine monophosphate modulators affects both oocyte and blastocyt ultrastructure. Reprod Fertil Dev. 2015;28:227. DOI: http://dx.doi.org/10.1071/RDv28n2Ab192

Richani D, Wang X, Zeng HT, Smitz J, Thompson JG, Gilchrist RB. Pre-maturation with CAMP modulators in conjunction with EGF-like peptides during in vitro maturation enhances mouse oocyte developmental competence. Mol Reprod Dev. 2014;81:422-35. PMID: 24488930 DOI: http://dx.doi.org/10.1002/mrd.22307

Richards JS, Russell DL, Ochsner S, Espey LL. Ovulation: new dimensions and new regulators of the inflammatory-like response. Annu Rev Physiol. 2002;64:69-92. PMID: 11826264 DOI: http://dx.doi.org/10.1146/annurev.physiol.64.081501.131029

Rose RD, Gilchrist RB, Kelly JM, Thompson JG, Sutton-McDowall ML. Regulation of sheep oocyte maturation using CAMP modulators. Theriogenology. 2013;79:142-8. PMID: 23102843 DOI: http://dx.doi.org/10.1016/j.theriogenology.2012.09.020 
Sadler SE, Maller JL. A similar pool of cyclic AMP phosphodiesterase in Xenopus oocytes is stimulated by insulin, insulin-like growth factor 1, and [Val12,Thr59]Ha-ras protein. ] Biol Chem. 1989;264:856-61. PMID: 2463250

Santiquet N, Papillon-Dion E, Djender N, Guillemette C, Richard FJ. New elements in the C-type natriuretic peptide signaling pathway inhibiting swine in vitro oocyte meiotic resumption. Biol Reprod. 2014a;91:16. PMID: 24899572 DOI: http://dx.doi.org/10.1095/biolreprod.113.114132

Santiquet N, Greene AF, Schoolcraft WB, Krisher RL. 313 Pre-in vitro maturation with cylic amp and cyclic gmp modulators improves developmental competece of mouse oocytes. Reprod Fertil Dev. 2014b;27:245. DOI: http://dx.doi.org/10.1071/RDv27n1Ab313

Santonocito M, Vento M, Guglielmino MR, Battaglia R, Wahlgren J, Ragusa M, Barbagallo D, Borzì P, Rizzari S, Maugeri M, Scollo P, Tatone C, Valadi H, Purrello M, Di Pietro C. Molecular characterization of exosomes and their microRNA cargo in human follicular fluid: bioinformatic analysis reveals that exosomal microRNAs control pathways involved in follicular maturation. Fertil Steril. 2014;102:1751-61.e1. PMID: 25241362 DOI: http://dx.doi.org/10.1016/j.fertnstert.2014.08.005

Sasseville M, Albuz FK, Côté N, Guillemette C, Gilchrist RB, Richard FJ. Characterization of novel phosphodiesterases in the bovine ovarian follicle. Biol Reprod. 2009;81:415-25. PMID: 19357367 DOI: http://dx.doi.org/10.1095/biolreprod.108.074450

Sasseville M, Côté N, Gagnon MC, Richard FJ. Up-regulation of $3^{\prime} 5^{\prime}$-cyclic guanosine monophosphate-specific phosphodiesterase in the porcine cumulus-oocyte complex affects steroidogenesis during in vitro maturation. Endocrinology. 2008;149:5568-76. PMID: 18669600 DOI: http://dx.doi.org/10.1210/en.2008-0547

Schwarz KR, Pires PR, Adona PR, Câmara de Bem TH, Leal $\mathrm{CL}$. Influence of nitric oxide during maturation on bovine oocyte meiosis and embryo development in vitro. Reprod Fertil Dev. 2008;20:529-36. PMID: 18462616 DOI: http://dx.doi.org/10.1071/RD07209

Schwarz KR, Pires PR, de Bem TH, Adona PR, Leal CL. Consequences of nitric oxide synthase inhibition during bovine oocyte maturation on meiosis and embryo development. Reprod Domest Anim. 2010;45:75-80. PMID: 20137060 DOI: http://dx.doi.org/10.1111/j.1439-0531.2008.01242.x

Sela-Abramovich S, Galiani D, Nevo N, Dekel N. Inhibition of rat oocyte maturation and ovulation by nitric oxide: mechanism of action. Biol Reprod. 2008;78:1111-8. PMID: 18337515 DOI: http://dx.doi.org/10.1095/biolreprod.107.065490

Shimada M, Nishibori M, Isobe N, Kawano N, Terada T. Luteinizing hormone receptor formation in cumulus cells surrounding porcine oocytes and its role during meiotic maturation of porcine oocytes. Biol Reprod. 2003;68:1142-9. PMID: 12606491 DOI: http://dx.doi.org/10.1095/biolreprod.102.010082

Shu YM, Zeng HT, Ren Z, Zhuang GL, Liang XY, Shen HW, Yao $\mathrm{SZ}$, Ke PQ, Wang NN. Effects of cilostamide and forskolin on the meiotic resumption and embryonic development of immature human oocytes. Hum Reprod. 2008;23:504-13. PMID: 1821603 DOI: http://dx.doi.org/10.1093/humrep/dem344
Shuhaibar LC, Egbert JR, Norris RP, Lampe PD, Nikolaev VO, Thunemann M, Wen L, Feil R, Jaffe LA. Intercellular signaling via cyclic GMP diffusion through gap junctions restarts meiosis in mouse ovarian follicles. Proc Natl Acad Sci U S A. 2015;112:5527-32. PMID: 25775542 DOI: http://dx.doi.org/10.1073/pnas.1423598112

Simon AM, Goodenough DA, Li E, Paul DL. Female infertility in mice lacking connexin 37. Nature. 1997;385:525-9. PMID: 9020357 DOI: http://dx.doi.org/10.1038/385525a0

Sirard MA, First NL. In vitro inhibition of oocyte nuclear maturation in the bovine. Biol Reprod. 1988;39:229-34. PMID: 2460146 DOI: http://dx.doi.org/10.1095/biolreprod39.2.229

Sirard MA, Richard F, Mayes M. Controlling meiotic resumption in bovine oocytes: a review. Theriogenology. 1998;49:483-97. PMID: 10732029 DOI: http://dx.doi.org/10.1016/S0093-691X(97)00420-2

Smitz JE, Thompson JG, Gilchrist RB. The promise of in vitro maturation in assisted reproduction and fertility preservation. Semin Reprod Med. 2011;29:24-37. PMID: 21207332 DOI: http://dx.doi.org/10.1055/s-0030-1268701

Sohel MM, Hoelker M, Noferesti SS, Salilew-Wondim D, Tholen E, Looft C, Rings F, Uddin MJ, Spencer TE, Schellander K, Tesfaye D. Exosomal and Non-Exosomal Transport of Extra-Cellular microRNAs in Follicular Fluid: Implications for Bovine Oocyte Developmental Competence. PLoS One. 2013;8:e78505. PMID: 24223816 DOI: https://doi.org/10.1371/journal.pone.0078505

Su YQ, Sugiura K, Wigglesworth K, O'Brien MJ, Affourtit JP, Pangas SA, Matzuk MM, Eppig JJ. Oocyte regulation of metabolic cooperativity between mouse cumulus cells and oocytes: BMP15 and GDF9 control cholesterol biosynthesis in cumulus cells. Development. 2008;135:111-21. PMID: 18045843 DOI: http://dx.doi.org/10.1242/dev.009068

Sugiura K, Pendola FL, Eppig JJ. Oocyte control of metabolic cooperativity between oocytes and companion granulosa cells: energy metabolism. Dev Biol. 2005;279:20-30. PMID: 15708555 DOI: http://dx.doi.org/10.1016/j.ydbio.2004.11.027

Sutton $M L$, Cetica PD, Beconi MT, Kind $K L$, Gilchrist RB, Thompson JG. Influence of oocyte-secreted factors and culture duration on the metabolic activity of bovine cumulus cell complexes. Reproduction. 2003;126:27-34. PMID: 12814344 DOI: http://dx.doi.org/10.1530/rep.0.1260027

Sutton-McDowall ML, Gilchrist RB, Thompson JG. The pivotal role of glucose metabolism in determining oocyte developmental competence. Reproduction. 2010;139:685-95. PMID: 20089664 DOI: http://dx.doi.org/10.1530/REP-09-0345

Thomas RE, Armstrong DT, Gilchrist RB. Differential effects of specific phosphodiesterase isoenzyme inhibitors on bovine oocyte meiotic maturation. Dev Biol. 2002;244:215-5. PMID: 11944932 DOI: http://dx.doi.org/10.1006/dbio.2002.0609

Thomas RE, Armstrong DT, Gilchrist RB. Bovine cumulus cell-oocyte gap junctional communication during in vitro maturation in response to manipulation of cell-specific cyclic adenosine 3',5'-monophosophate levels. Biol Reprod. 2004a;70:548-56. PMID: 14568915 DOI: http://dx.doi.org/10.1095/biolreprod.103.021204 
Thomas RE, Thompson JG, Armstrong DT, Gilchrist RB. Effect of specific phosphodiesterase isoenzyme inhibitors during in vitro maturation of bovine oocytes on meiotic and developmental capacity. Biol Reprod. 2004b;71:1142-9. PMID: 15189837 DOI: http://dx.doi.org/10.1095/biolreprod.103.024828

Tichovská H, Petr J, Chmelíková E, Sedmíková M, Tůmová L, Krejcová M, Dörflerová A, Rajmon R. Nitric oxide and meiotic competence of porcine oocytes. Animal. 2011;5:1398-405. PMID: 22440285 DOI: http://dx.doi.org/10.1017/S1751731111000565

Tsafriri A, Chun SY, Zhang R, Hsueh AJ, Conti M. Oocyte maturation involves compartmentalization and opposing changes of CAMP levels in follicular somatic and germ cells: studies using selective phosphodiesterase inhibitors. Dev Biol. 1996;178:393-402. PMID: 8812137 DOI: http://dx.doi.org/10.1006/dbio.1996.0226

Tsuji T, Kiyosu C, Akiyama K, Kunieda T. CNP/NPR2 signaling maintains oocyte meiotic arrest in early antral follicles and is suppressed by EGFR-mediated signaling in preovulatory follicles. Mol Reprod Dev. 2012;79:795-802. PMID: 22987720 DOI: http://dx.doi.org/10.1002/mrd.22114

Ulloa SM, Heinzmann J, Herrmann D, Timmermann B, Baulain U, Großfeld R, Diederich M, Lucas-Hahn A, Niemann $H$. Effects of different oocyte retrieval and in vitro maturation systems on bovine embryo development and quality. Zygote. 2015;23:367-77. PMID: 24423448 DOI: http://dx.doi.org/10.1017/S0967199413000658

van den Hurk R, Zhao J. Formation of mammalian oocytes and their growth, differentiation and maturation within ovarian follicles. Theriogenology. 2005;63:1717-51. PMID: 15763114DOI: http://dx.doi.org/10.1016/j.theriogenology.2004.08.005

Vanhoutte L, De Sutter P, Nogueira D, Gerris J, Dhont M, Van der Elst J. Nuclear and cytoplasmic maturation of in vitro matured human oocytes after temporary nuclear arrest by phosphodiesterase 3-inhibitor. Hum Reprod. 2007;22:1239-46. PMID: 17303631 DOI: http://dx.doi.org/10.1093/humrep/dem007

Vanhoutte L, Nogueira D, Dumortier F, De Sutter P. Assessment of a new in vitro maturation system for mouse and human cumulus-enclosed oocytes: three-dimensional prematuration culture in the presence of a phosphodiesterase 3-inhibitor. Hum Reprod. 2009;24:1946-59. PMID: 19395363 DOI: http://dx.doi.org/10.1093/humrep/dep104

Vanhoutte L, Nogueira D, Gerris J, Dhont M, De Sutter P. Effect of temporary nuclear arrest by phosphodiesterase 3-inhibitor on morphological and functional aspects of in vitro matured mouse oocytes. Mol Reprod Dev. 2008;75:1021-30. PMID: 18163445 DOI: http://dx.doi.org/10.1002/mrd.20851
Varani S, Elvin JA, Yan C, DeMayo J, DeMayo FJ, Horton $\mathrm{HF}$, Byrne MC, Matzuk MM. Knockout of pentraxin 3, a downstream target of growth differentiation factor-9, causes female subfertility. Mol Endocrinol. 2002;16:1154-67. PMID: 12040004 DOI: http://dx.doi.org/10.1210/mend.16.6.0859

Wright PT, Schobesberger S, Gorelik J. Studying GPCR/ CAMP pharmacology from the perspective of cellular structure. Front Pharmacol. 2015;6:148. PMID: 26236239 DOI: https://doi.org/10.3389/fphar.2015.00148

Young JM, McNeilly AS. Theca: the forgotten cell of the ovarian follicle. Reproduction. 2010;140:489-504. PMID: 20628033 DOI: http://dx.doi.org/10.1530/REP-10-0094

Zeng HT, Ren $Z$, Guzman L, Wang $X$, Sutton-McDowall ML, Ritter LJ, De Vos M, Smitz J, Thompson JG, Gilchrist RB. Heparin and CAMP modulators interact during pre-in vitro maturation to affect mouse and human oocyte meiosis and developmental competence. Hum Reprod. 2013;28:1536-45. PMID: 23559189 DOI: http://dx.doi.org/10.1093/humrep/det086

Zeng HT, Richani D, Sutton-McDowall ML, Ren Z, Smitz JE, Stokes Y, Gilchrist RB, Thompson JG. Prematuration with cyclic adenosine monophosphate modulators alters cumulus cell and oocyte metabolism and enhances developmental competence of in vitro-matured mouse oocytes. Biol Reprod. 2014;91:47. PMID: 24966394 DOI: http://dx.doi.org/10.1095/biolreprod.114.118471

Zhang J, Wei Q, Cai J, Zhao X, Ma B. Effect of C-Type Natriuretic Peptide on Maturation and Developmental Competence of Goat Oocytes Matured In Vitro. PLoS One. 2015;10:e0132318. PMID: 26151446 DOI: https://doi.org/10.1371/journal.pone.0132318

Zhang M, Su YQ, Sugiura K, Wigglesworth K, Xia G, Eppig JJ. Estradiol promotes and maintains cumulus cell expression of natriuretic peptide receptor 2 (NPR2) and meiotic arrest in mouse oocytes in vitro. Endocrinology. 2011;152:4377-85. PMID: 21914782 DOI: http://dx.doi.org/10.1210/en.2011-1118

Zhang M, Su YQ, Sugiura K, Xia G, Eppig JJ. Granulosa cell ligand NPPC and its receptor NPR2 maintain meiotic arrest in mouse oocytes. Science. 2010;330:366-9. PMID: 20947764 DOI: http://dx.doi.org/10.1126/science.1193573

Zhang W, Yang $Y$, Liu W, Chen Q, Wang $H$, Wang $X$, Zhang Y, Zhang M, Xia G. Brain natriuretic peptide and C-type natriuretic peptide maintain porcine oocyte meiotic arrest. J Cell Physiol. 2014;230:71-81. PMID: 24912131 DOI: http://dx.doi.org/10.1002/jcp.24682 